\title{
Posisi Setengah Terlentang pada Teknik Alexander untuk Mengatasi Nervous Pemula Dewasa Saat Memainkan Piano
}

\author{
The Semi-Supine in Alexander Technicque \\ to Overcome Adult Beginner Student's Nervous while Playing Piano
}

\author{
Auliya Ayu Annisa, Diah Latifah \\ Pendidikan Seni Musik, Universitas Pendidikan Indonesia, Bandung, Jawa Barat, Indonesia \\ ayu@upi.edu
}

Naskah diterima tanggal 07/03/2019, direvisi akhir tanggal 22/04/2019, disetujui tanggal 30/04/2019

\begin{abstract}
Abstrak
Penelitian ini didasarkan atas kondisi nervous dua pemula dewasa saat bermain piano di pelatihan piano. Siswa piano dengan usia 18 tahun atau lebih dikategorikan sebagai pemula dewasa. Penelitian ini bertujuan untuk mengetahui, keunggulan dan kelemahan penerapan teknik Alexander posisi setengah terlentang dalam mengatasi nervous pemula dewasa pada pelatihan piano. Teknik Alexander posisi setengah terlentang merupakan posisi istirahat yang sangat efektif. Tidak hanya untuk melepaskan ketegangan tetapi juga memiliki efek untuk meningkatkan koordinasi antara kepala, leher, dan tulang belakang. Melalui posisi setengah terlentang, pemula dewasa menjadi lebih relaks untuk memainkan piano. Posisi setengah terlentang diterapkan pada pemula dewasa melalui 2 siklus. Metode yang digunakan dalam penelitian ini adalah Design Based Research dengan pendekatan kualitatif yang berkarakter fenomenologis. Teknik pengumpulan data yang digunakan yakni wawancara, observasi, dan dokumentasi. Hasil dari penelitian ini adalah melalui penerapan teknik Alexander posisi setengah terlentang pada pelatihan piano, pemula dewasa dapat mengatasi nervous nya tanpa mengikuti perawatan medis atau pelaksanaan terapi.
\end{abstract}

Kata kunci: Posisi Setengah Terlentang, Nervous, Pemula Dewasa, Pelatihan Piano

\begin{abstract}
This research was based on the nervous condition of two adult beginners while playing the piano on piano training. Piano students aged 18 years or older are categorized as adult beginners. This study aims to find out, the advantages and disadvantages of applying Alexander's technique to the semi-supine position in overcoming nervous adult beginners on piano training. Alexander's half-supine position is a very effective resting position. Not only to release tension but also have the effect of increasing coordination between the head, neck and spine. Through a half-supine position, adult beginners become more relaxed to play the piano. The semi-supine position is applied to adult beginners through 2 cycles. The method used in this study is Design Based Research with a qualitative approach that has phenomenological characteristics. The data collection techniques are interviews, observation, and documentation. The results of this study are through the application of Alexander's technique to a half-stretched position on piano training, adult beginners can overcome their nervousness without taking medical care or doing therapy.
\end{abstract}

Keywords: The Semi-Supine, Nervous, Adult Beginner, Piano Training

\section{PENDAHULUAN}

Dewasa ini semakin banyak orang yang ingin mempelajari instrumen musik yang diminati oleh anak-anak maupun orang dewasa (David, 2017, hlm.1). Meskipun pelatihan piano tingkat pemula biasanya 
dipelajari oleh anak-anak, tetapi kenyataan menujukan bahwa piano tingkat pemula juga diminati oleh orang-orang dewasa (Erricson dkk., 1993; Davidson dkk., 1996). Kalangan dewasa dengan usia 18 tahun ke atas yang menginginkan belajar piano termasuk ke dalam kategori pemula dewasa. Hal ini sesuai dengan salah satu kategori siswa piano pemula dewasa yang dikemukakakan oleh Uszler (Mei, 2008, hlm.1) College nonmusic majors (roughly eighteen to twentyfour years old.

Penelitian ini dilaksanakan karena terdapatnya fakta faktual dua siswa pemula dewasa pada pelatihan piano di sekolah musik Triplet Rancaekek Kabupaten Bandung yang mengalami kondisi nervous saat proses belajar piano khususnya ketika belajar bersama guru. Menurut kamus Oxford (2005, hlm. 287) nervous yaitu "...anxious obout something, afraid of something, easily worried or frightened." Berdasarkan definisi tersebut maka nervous adalah perasaan cemas terhadap sesuatu, takut terhadap sesuatu, mudah cemas atau gugup. Kondisi yang dialami pemula dewasa penderita nervous adalah jari gemetar saat memainkan piano, berkeringat dingin, tangan dingin, muka memerah dan bahu yang naik. Gejala-gejala ini terindikasi sebagai gejala nervous. Dilangsir dari penelitan D. Lofnes yang berjudul Dealling with Neourvosness, Øiestad (Lofnes, 2010, hlm.8) mengemukakan bahwa,

Reactions on nervousness are interpreted as a sign that you will not manage the situation or as an expression for all your shortcomings, "It's typical of me, I'm always making a fool out of myself", which again strengthen the nervousness.

Berdasarkan teori tersebut maka nervous dalam bermain piano diinterpretasikan sebagai sebuah keadaan dimana siswa pemula dewasa tidak dapat menguasai situasi saat bermain piano. Padahal nervous merupakan sesuatu hal yang normal bagi setiap orang pada banyak situasi, terdapat orang-orang yang memiliki reaksi nervous pada tubuhnya seperti, denyut nadi yang meningkat, muka memerah, berkeringat dingin dan gemetar.

Hal ini sesuai dengan gejala nervous dalam bermain piano yang dikemukakan oleh profesor neorologi dari Amerika, Antonio Damasio. Damasio (Lofnes, 2010) mengemukakan bahwa,

One of the problems for persons with low self-esteem is that they tend to interpret emotions in a negative way. They seem to forget that it is normal to feel nervous in many situations, and that everybody gets nervous reactions in the body, like increased pulse, blushing, cold sweating and the feeling of trembling. (hlm.8)

Karena permasalahan tersebut, pemula dewasa tidak bisa menyelesaikan materi pelatihan piano dengan optimal. Untuk mengatasi permasalahan tersebut, maka perlu diadakan suatu solusi atau pemecahan masalah. Didasarkan atas hasil identifikasi penyelesaian masalah nervous. Solusi permasalahan yang memungkinkan adalah penerapan gerakan the semi supine temuan Alexander. Hal ini sejalan dengan teori Heirich (2005) yang mengemukakan bahwa,

Semi-Supine is found to be a very effective resting position, yet it is more than merely restful. Not only does it give us an opportunity to undo the excess habitual tensions of our daily lives, but it also has the profound effect of reorganizing the head, neck, and spine. Therefore it is restorative and "constructive" as well as restful. (hlm.49)

Berdasarkan penjelasan tersebut 
maka posisi setengah terlentang merupakan posisi istirahat yang sangat efektif. Tidak hanya untuk melepaskan ketegangan tetapi juga memiliki efek untuk meningkatkan koordinasi antara kepala, leher, dan tulang belakang. Melalui posisi setengah terlentang, pemula dewasa menjadi lebih relaks untuk memainkan piano.

The semi-supine merupakan posisi setengah terlentang. Dimana posisi ini merupakan salah satu gerakan Alexander Technique. The semi-supine adalah istilah spesifik pada teknik Alexander. Pada posisi setengah terlentang, pemula dewasa berbaring di lantai dengan lutut ditekuk, kaki bertumpu pada lantai dan kepala bertumpu pada satu buku atau lebih. Hal ini sejalan dengan teori yang dikemukakan Heirich (2005, hlm.49) bahwa,

The adult beginners are going to lie down on their back on a firm surface with their head on 1-2 inches of paperback books, your knees bent with feet flat on the floor, approximately hip-width apart. The firm surface can be a carpeted floor, an exercise mat or something similar, but not a mattress unless it is a very compact futon.

Berdasarkan teori tersebut, buku dijadikan sebagai bantalan kepala partisipan, jumlah buku yang dijadikan sebagai spartisipanran kepala pemula dewasa disesuaikan dengan postur tubuh pemula dewasa. Jika bahu mereka berbentuk bulat maka pemula dewasa membutuhkan buku dengan ketebalan 2 inci. Namun jika bahu mereka cenderung berbentuk datar maka pemula dewasa membutuhkan buku dengan ketebalan sekitar 1 inci. Jika ketebalan buku kurang sesuai maka dapat terjadi dagu mereka akan mengarah ke atas tetapi jika buku terlalu tebal maka tenggorokan dan laring mereka akan tertekan.

Tujuan penggunaan buku sebagai tumpuan pada kepala adalah untuk memberikan pengangkatan yang cukup pada kepala sehingga gravitasi memberikan traksi yang aman dan lembut ke tulang belakang, dimulai dengan leher, sepanjang tulang belakang dan tulang ekor.

Terdapat beberapa studi terkait yang berhubungan dengan cara mengatasi nervous pemain piano pada pertunjukan musik melalui gerakan posisi setengah terlentang (Francoli, 2010; King, 2013). Hal ini sejalan dengan teori yang dikemukakan oleh Heirich (2005, hlm.49),

Semi-Supine is found to be a very effective resting position, yet it is more than merely restful. Not only does it give us an opportunity to undo the excess habitual tensions of our daily lives, but it also has the profound effect of reorganizing the head, neck, and spine. Therefore it is restorative and "constructive" as well as restful.

Berdasarkan penjelasan tersebut maka posisi setengah terlentang merupakan posisi istirahat yang sangat efektif. Tidak hanya untuk melepaskan ketegangan tetapi juga memiliki efek untuk meningkatkan koordinasi antara kepala, leher, dan tulang belakang. Melalui posisi setengah terlentang, pemula dewasa menjadi lebih relaks untuk memainkan piano.

\section{METODE PENELITIAN}

Kegiatan penelitian ini menggunakan metode penelitian DBR (Design Based Research) dengan karakter fenomenologis berpendekatan kualitatif. DBR merupakan desain metodologi penelitian yang dirancang dan diperentukan untuk pendidik yang bertujuan untuk meningkatkan dampak, transfer, dan translasi penelitian pendidikan untuk meningkatkan kegiatan praktik melalui pengembangan teori (Anderson \& Sattuck, 2012; DBRC, 2003; Dede, 2005; 
Kali, 2008; Pool \& Dorothy, 2016; Shattuck \& Anderson, 2013; Wang \& Hannafin, 2005; Wong dkk., 2011). Dikatakan fenomenologis karena penelitian ini belum pernah dilakukan di Indonesia.
Reeves mengemukakan langkahlangkah desain penelitian dengan menggunakan pendekatan DBR yang dirumuskan ke dalam gambar 1 berikut (Amiel \& Reeves, 2008, hlm. 34),

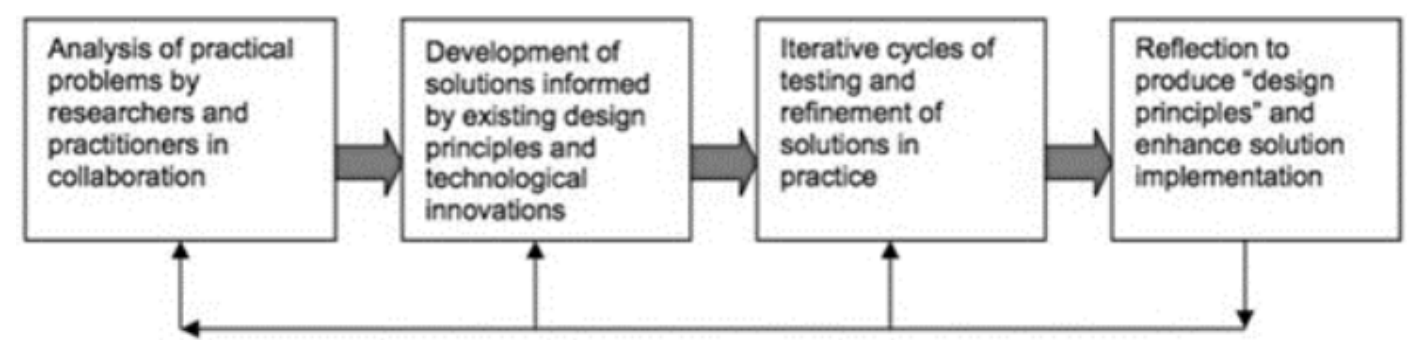

Gambar 1. Design-Based Research by Reeves 2006

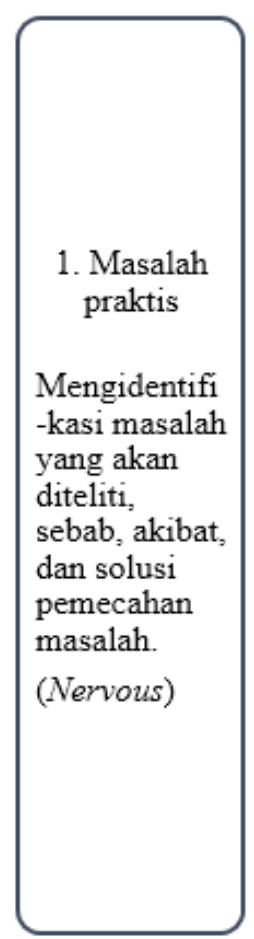

\begin{tabular}{|l|}
\hline \multicolumn{1}{|c|}{2.} \\
Perancangan \\
Merancang \\
solusi \\
terhadap \\
masalah, \\
beserta \\
dengan \\
program- \\
program \\
yang akan \\
dilakukan \\
dalam proses \\
pelatihan, \\
serta \\
persiapan \\
tempat, \\
peserta didik, \\
waktu, dan \\
lainnya. \\
(Gerakan \\
The Semi \\
Supine) \\
\hline
\end{tabular}
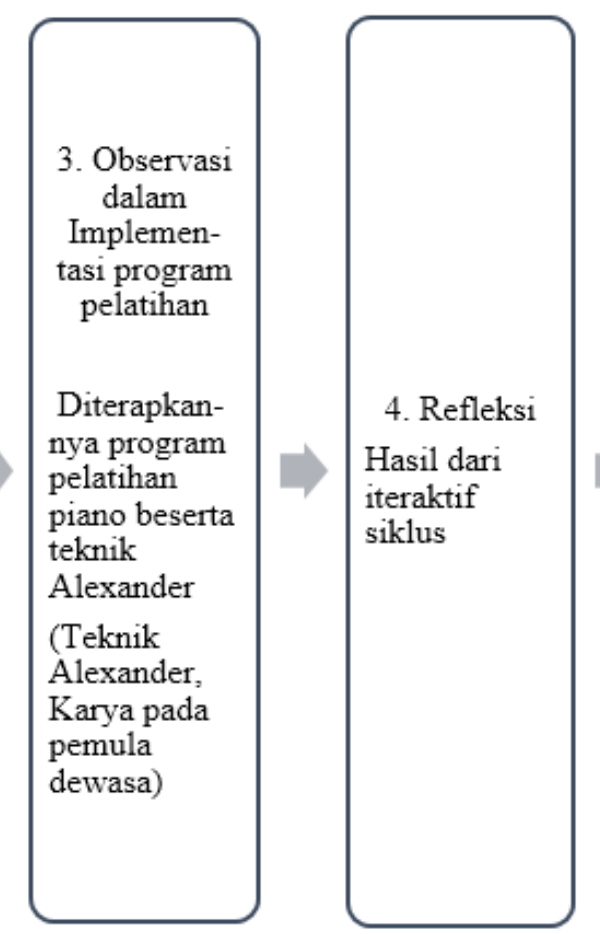

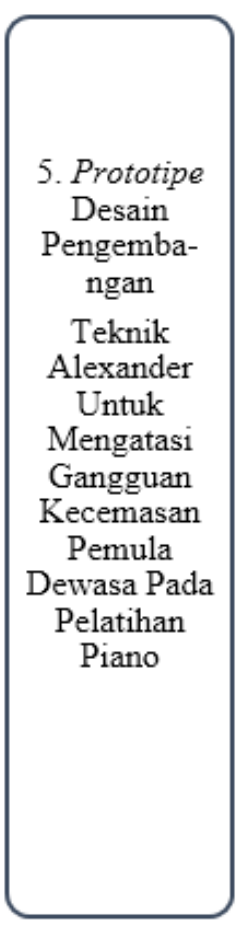

Gambar 2. Langkah Penelitian

Penelitian ini mengembangkan model pelatihan piano bagi pemula dewasa untuk mengatasi nervous melalui 2 siklus atau 6 pertemuan. Tahap identifikasi dan analisis masalah merupakan awal dimulainya penelitian, dimana peneliti menemukan permasalahan nervous pada kedua pemula dewasa sehingga pemula dewasa tidak dapat menyelesaikan karya bermain piano dengan baik. Berdasarkan fakta tersebut maka peneltiti menerapkan posisi setengah terlentang untuk mengatasi permasalah tersebut. Beikut ini merupakan penjelasan gambar 2 dari langkah penelitian ini yaitu:

\section{Siklus I}

1. Tahap perencanaan merupakan tahapan dimana penliti merancang subjek penelitian, menentukan tempat penelitian, menentukan waktu penelitian, serta membuat bahan ajar untuk pelatihan piano.

2. Tahap implementasi program pelatihan. Setelah melakukan observasi awal, 
peneliti mulai dengan menerapkan program pelatihan piano yang dilanjutkan dengan pelaksanaan tindakan posisi setengah terlentang yang diterapkan oleh guru kepada pemula dewasa dengan tahapan sebagai berikut:

a. Guru mendemonstrasikan gerakan the semi-supine;

b. Guru menginstruksikan pemula dewasa untuk memperhatikan demonstrasi guru;

c. Guru menginstruksikan pemula dewasa untuk melakukan gerakan the semi-supine;

d. Guru menginstruksikan pemula dewasa untuk menekuk lututnya ke lantai;

e. Guru menginstruksikan pemula dewasa untuk menyimpan bukunya di lantai (posisi buku berada di sebelah kiri, di depan pemula dewasa berlutut, sekitar 1 meter atau lebih dari posisi pemula dewasa berlutut);

f. Guru menginstruksikan pemula dewasa untuk membungkukan punggungnya sampai tulang belakang pemula dewasa lurus dan menyimpan kepalanya di atas buku;

g. Guru menginstruksikan pemula dewasa untuk berbaring dan meletakkan kepalanya di atas buku;

h. Guru menginstruksikan pemula dewasa untuk menekuk lututnya saat berbaring dan menyimpan kedua telapak kakinya di lantai;

i. Guru menginstruksikan pemula dewasa untuk membiarkan tubuhnya berada dalam posisi terebut untuk beberapa saat sambil bernafas;

j. Guru menginstruksikan pemula dewasa untuk memposisikan kedua tangannya pada samping perut;

k. Guru menginstruksikan pemula dewasa untuk mengangkat kedua tangannya kesamping sambil menarik nafas dan memposisikan kedua tangannya kembali. Pemula dewasa melakukan hal tersebut berulangulang selama sepuluh kali;

1. Guru menginstruksikan pemula dewasa untuk memposisikan tubuhnya seperti bayi yang sedang merangkak;

m. Guru menginstruksikan pemula dewasa untuk mengambil buku;

n. Guru menginstruksikan pemula dewasa untuk berdiri dengan tegak.

Observer melakukan pengamatan dengan menggunakan instrumen lembar observasi untuk mencatat pelaksanaan tindakan yang dicatat oleh peneliti. Tindakan ini dilaksanakan sebanyak dua kali pertemuan.

3. Tahap refleksi merupakan tahap dimana peneliti mendiskusikan hasil penelitiannya ke sesama pengajar piano. Tujuan dari diskusi ini juga untuk mendapatkan jawaban dari pertanyaanpertanyaan yang timbul saat jalannya proses penelitian, misalnya mengapa pemula dewasa ini mengalami nervous saat memainkan piano. Setelah selesai menjalankan semua tahapan, peneliti merangkum keseluruhan hasil untuk dievaluasi terhadap subjeknya, dan juga dikaitkan dengan data observasi awal setiap pemula dewasa.

\section{Siklus II}

1. Tahap perencanaan merupakan tahapan dimana penliti merancang subjek penelitian, menentukan tempat penelitian, menentukan waktu penelitian, serta membuat bahan ajar untuk pelatihan piano.

2. Tahap implementasi program pelatihan. Setelah melakukan observasi awal, peneliti mulai dengan menerapkan program pelatihan piano yang dilanjutkan dengan pelaksanaan tindakan posisi setengah terlentang dengan menambahkan tindakan 
psikologis diterapkan oleh guru kepada pemula dewasa dengan menanyakan pertanyaan sebagai berikut:

a. Bayangkan bahwa partisipan sedang memberikan pertunjukan piano.

b. Dimana partisipan sekarang? Diatas bawah, kiri, atau kanan panggung?

c. Jika partisipan tidak gelisah sekarang, ingatlah apa yang partisipan rasakan saat ini.

d. Bayangkan seluruh bagian tubuh partisipan.

e. Sadarilah bahwa kecemasan adalah rekasi terhadap terhadap permainan piano partisipan. Hadapilah! Kecemasan itu adalah sesuatu yang ada dibawah kontrol partisipan.

f. Buatlah keputusan sadar untuk melakukan sesuatu yang berbeda dalam menanggapi perasaan kali ini. Agar perasaan itu berubah, partisipan hanya akan membiarkan perasaan itu berada di sana, beri diri Partisipan kebebasan untuk merasakannya terlebih dahulu.

g. Pilih sensasi yang yang akan partisipan rasakan saat ini, dan berikan rasa ingin tahu tentang hal itu.

h. Katakan pada diri partisipan seperti apa rasanya.

i. Apakah partisipan benar-benar merasakan perasaan ini?

j. Untuk beberapa saat, tanpa berusaha membuat rasa cemas hilang. Jangan mencoba bersantai, bergerak, atau melakukan hal lain. Tetap rasakan perasaan ini, temukan itu menarik, dan biarkan tidak nyaman.

k. Adakah perasaan lain yang sepertinya menarik perhatian partisipan? Jika ada alihkan perasaan partisipan kepada perasaan ini, tanyakan tentang hal itu pada diri partisipan. Kembali ke no. 8, dan sesering yang partisipan suka.
Observer melakukan pengamatan dengan menggunakan instrumen lembar observasi untuk mencatat pelaksanaan tindakan yang dicatat oleh peneliti. Tindakan ini dilaksanakan sebanyak dua kali pertemuan.

3. Tahap refleksi merupakan tahap dimana peneliti mendiskusikan hasil penelitiannya ke sesama pengajar piano. Tujuan dari diskusi ini juga untuk mendapatkan jawaban dari pertanyaan-pertanyaan yang timbul saat jalannya proses penelitian, misalnya mengapa pemula dewasa ini mengalami nervous saat memainkan piano. Setelah selesai menjalankan semua tahapan, peneliti merangkum keseluruhan hasil untuk dievaluasi terhadap subjeknya, dan juga dikaitkan dengan data observasi awal setiap pemula dewasa.

Dilihat apa keterkaitan antara hasil penelitian dengan observasi awal terhadap pemula dewasa. Berdasarkan hasil akhir tersebut,makapenelitianiniakandikerucutkan menjadi, gerakan setengah terlentang untuk mengatasi nervous pada siswa usia dewasa saat memainkan piano. sehingga model ini dapat digunakan untuk semua guru piano yang memiliki permasalahan yang sama pada pemula dewasa penderita nervous.

Partisipan pada penelitian ini adalah peneliti sebagai guru piano, psikolog, dua pemula dewasa, dan observer. Instrumen pada penelitian ini adalah pedoman observasi, tes, pedoman wawancara, dan Video Camera Recorder (VCR) sebagai alat untuk mendokumentasikan kegiatan penelitian. Tedapat beberapa teknik pengumpulan data yang dilakukan yakni wawancara, observasi, dan dokumentasi.

\section{HASIL DAN PEMBAHASAN 3.1 Hasil}

Hasil pre-test menunjukan bahwa dua pemula dewasa mengalami nervous. Gejala nervous yang ditunjukan pada pemula dewasa ke-1 adalah, muka memerah, tangan dan 
dahi berkeringat keringat. Sedangakan pada pemula dewasa ke-2, gejala nervous yang timbul adalah tangan dingin, dan bahu naik. Sehingga kedua pemula dewasa tidak dapat memainkan karya dengan optimal. Setelah mengidentifikasi masalah pada pemula dewasa, peneliti melanjutkan penelitian ini pada tahap perancangan. Peneliti akan menggunakan 2 siklus. Pada siklus I peneliti akan memberikan tindakan posisi setengah terlentang sebanyak 3 kali. Pada siklus II peneliti akan memberikan tindakan posisi setengah terlentang dengan menambahkan tindakan psikologis sebanyak 2 kali.

\section{Siklus I}

\section{Pertemuan 1}

1. Tahap Perencanaan

Peneliti mengatur waktu pertemuan, menyiapkan materi dan media penelitian.

2. Tahap Observasi dan Implementasi Posisi Setengah Terlentang.

Tindakan yang diberikan adalah dengan memberikan materi pelatihan piano yaitu: Tangga nada C Mayor (R.H \& L.H), Kadens C Mayor, Trinada C Mayor, Beyer No.2. Kemudian peneliti menerapakan posisi setengah terlentang dengan tindakan sebagai berikut :

a. Guru mendemonstrasikan gerakan the semi-supine;

b. Guru menginstruksikan pemula dewasa untuk memperhatikan demonstrasi guru;

c. Guru menginstruksikan pemula dewasa untuk melakukan gerakan the semi-supine;

d. Guru menginstruksikan pemula dewasa untuk menekuk lututnya ke lantai;

e. Guru menginstruksikan pemula dewasa untuk menyimpan bukunya di lantai (posisi buku berada di sebelah kiri, di depan pemula dewasa berlutut, sekitar 1 meter atau lebih dari posisi pemula dewasa berlutut);

f. Guru menginstruksikan pemula dewasa untuk membungkukan punggungnya sampai tulang belakang pemula dewasa lurus dan menyimpan kepalanya di atas buku;

g. Guru menginstruksikan pemula dewasa untuk berbaring dan meletakkan kepalanya di atas buku;

h. Guru menginstruksikan pemula dewasa untuk menekuk lututnya saat berbaring dan menyimpan kedua telapak kakinya di lantai;

i. Guru menginstruksikan pemula dewasa untuk membiarkan tubuhnya berada dalam posisi terebut untuk beberapa saat sambil bernafas;

j. Guru menginstruksikan pemula dewasa untuk memposisikan kedua tangannya pada samping perut;

k. Guru menginstruksikan pemula dewasa untuk mengangkat kedua tangannya kesamping sambil menarik nafas dan memposisikan kedua tangannya kembali. Pemula dewasa melakukan hal tersebut berulangulang selama sepuluh kali;

1. Guru menginstruksikan pemula dewasa untuk memposisikan tubuhnya seperti bayi yang sedang merangkak;

m. Guru menginstruksikan pemula dewasa untuk mengambil buku;

n. Guru menginstruksikan pemula dewasa untuk berdiri dengan tegak.

Setelah itu, peneliti melakukan post-test dengan materi A minor, trinada A minor (masing-masing tangan), dan Beyer No. 3 Berdasarkan hasil post-test pemula dewasa ke-1 masih menunjukan gejala nervous yang sama. Namun pada pemula dewasa ke-2, bahunya yang biasanya naik dan tegang. Mulai turun dan relaks untuk beberapa saat.

3. Tahap Refleksi

Berdasarkan hasil observasi, maka pada 
pertemuan berikutnya, peneliti akan memberikan tindakan the semi-supine pada kedua pemula dewasa.

\section{Pertemuan 2}

1. Tahap Perencanaan

Peneliti mengatur waktu pertemuan, menyiapkan materi dan media penelitian.

2. Tahap Observasi dan Implementasi Posisi Setengah Terlentang

Tindakan yang diberikan adalah dengan memberikan materi pelatihan piano yaitu: Tangga nada A minor (R.H \& L.H), Kadens A minor (R.H \& L.H), Trinada A minor (R.H \& L.H), Beyer No. 3 (R.H \& L.H). Kemudian peneliti menerapakan posisi setengah terlentang pada pemula dewasa dengan tindakan sebagai berikut:

a. Guru mendemonstrasikan gerakan the semi-supine;

b. Guru menginstruksikan pemula dewasa untuk memperhatikan demonstrasi guru;

c. Guru menginstruksikan pemula dewasa untuk melakukan gerakan the semi-supine;

d. Guru menginstruksikan pemula dewasa untuk menekuk lututnya ke lantai;

e. Guru menginstruksikan pemula dewasa untuk menyimpan bukunya di lantai (posisi buku berada di sebelah kiri, di depan pemula dewasa berlutut, sekitar 1 meter atau lebih dari posisi pemula dewasa berlutut);

f. Guru menginstruksikan pemula dewasa untuk membungkukan punggungnya sampai tulang belakang pemula dewasa lurus dan menyimpan kepalanya di atas buku;

g. Guru menginstruksikan pemula dewasa untuk berbaring dan meletakkan kepalanya di atas buku;

h. Guru menginstruksikan pemula dewasa untuk menekuk lututnya saat berbaring dan menyimpan kedua telapak kakinya di lantai;

i. Guru menginstruksikan pemula dewasa untuk membiarkan tubuhnya berada dalam posisi terebut untuk beberapa saat sambil bernafas;

j. Guru menginstruksikan pemula dewasa untuk memposisikan kedua tangannya pada samping perut;

k. Guru menginstruksikan pemula dewasa untuk mengangkat kedua tangannya kesamping sambil menarik nafas dan memposisikan kedua tangannya kembali. Pemula dewasa melakukan hal tersebut berulangulang selama sepuluh kali;

1. Guru menginstruksikan pemula dewasa untuk memposisikan tubuhnya seperti bayi yang sedang merangkak;

m. Guru menginstruksikan pemula dewasa untuk mengambil buku;

n. Guru menginstruksikan pemula dewasa untuk berdiri dengan tegak.

Setelah itu, peneliti melakukan posttest dengan materi Tangga nada G Mayor, Kadens G Mayor, Trinada G Mayor, Rock'n Roll Piano Study Book 1. Berdasarkan hasil post-test pemula dewasa ke-1 menunjukan gejala nervous tangan dan dahi berkeringat. Sedangkan pada pemula dewasa ke-2, bahunya sudah turun dan relaks, namun tangannya masih dingin.

3. Tahap Refleksi

Berdasarkan hasil observasi, maka pada pertemuan berikutnya, peneliti akan memberikan tindakan the semisupine dengan menambahkan tindakan psikologis kepada kedua pemula dewasa.

\section{Siklus II}

Pertemuan 1

1. Tahap Perencanaan

Peneliti mengatur waktu pertemuan, menyiapkan materi dan media penelitian.

2. Tahap Observasi dan Implementasi Posisi 
Setengah Terlentang

Tindakan yang diberikan adalah dengan memberikan materi pelatihan piano yaitu: Tangga nada G Mayor, Kadens G Mayor, Trinada G Mayor, Rock'n Roll Piano Study Book 1. Kemudian peneliti menerapakan posisi setengah terlentang dengan menambahkan tindakan psikologis dengan tindakan sebagai berikut :

a. Guru mendemonstrasikan gerakan the semi-supine;

b. Guru menginstruksikan pemula dewasa untuk memperhatikan demonstrasi guru;

c. Guru menginstruksikan pemula dewasa untuk melakukan gerakan the semi-supine;

d. Guru menginstruksikan pemula dewasa untuk menekuk lututnya ke lantai;

e. Guru menginstruksikan pemula dewasa untuk menyimpan bukunya di lantai (posisi buku berada di sebelah kiri, di depan pemula dewasa berlutut, sekitar 1 meter atau lebih dari posisi pemula dewasa berlutut);

f. Guru menginstruksikan pemula dewasa untuk membungkukan punggungnya sampai tulang belakang pemula dewasa lurus dan menyimpan kepalanya di atas buku;

g. Guru menginstruksikan pemula dewasa untuk berbaring dan meletakkan kepalanya di atas buku;

h. Guru menginstruksikan pemula dewasa untuk menekuk lututnya saat berbaring dan menyimpan kedua telapak kakinya di lantai;

i. Guru menginstruksikan pemula dewasa untuk membiarkan tubuhnya berada dalam posisi terebut untuk beberapa saat sambil bernafas;

j. Guru menginstruksikan pemula dewasa untuk memposisikan kedua tangannya pada samping perut;

k. Guru menginstruksikan pemula dewasa untuk mengangkat kedua tangannya kesamping sambil menarik nafas dan memposisikan kedua tangannya kembali. Pemula dewasa melakukan hal tersebut berulangulang selama sepuluh kali;

1. Guru memberikan pertanyaanpertanyaan dengan menggunakan pendekatan psikologis kepada pemula dewasa yaitu sebagai berikut:

1) Bayangkan bahwa partisipan sedang memberikan pertunjukan piano.

2) Dimana partisipan sekarang? Diatas, bawah, kiri, atau kanan panggung?

3) Jika partisipan tidak gelisah sekarang, ingatlah apa yang partisipan rasakan saat ini.

4) Bayangkan seluruh bagian tubuh partisipan.

5) Sadarilah bahwa kecemasan adalah rekasi terhadap terhadap permainan piano partisipan. Hadapilah! Kecemasan itu adalah sesuatu yang ada dibawah kontrol partisipan.

6) Buatlah keputusan sadar untuk melakukan sesuatu yang berbeda dalam menanggapi perasaan kali ini: Partisipan tidak akan melakukan hal yang sama, yang selalu partisipan lakukan. Agar perasaan itu berubah, Partisipan hanya akan membiarkan perasaan itu berada di sana, beri diri Partisipan kebebasan untuk merasakannya terlebih dahulu.

7) Pilih sensasi yang akan partisipan rasakan saat ini, dan berikan rasa ingin tahu tentang hal itu.

8) Katakan pada diri Partisipan seperti apa rasanya.

9) Apakah partisipan benar-benar Jurnal Penelitian Pendidikan 
merasakan perasaan ini?

10) Untuk beberapa saat, tanpa berusaha membuat rasa cemas hilang. Jangan mencoba bersantai, bergerak, atau melakukan hal lain. Tetap rasakan perasaan ini, temukan itu menarik, dan biarkan tidak nyaman.

11) Adakah perasaan lain yang menarik perhatian partisipan? Jika ada alihkan perasaan partisipan kepada perasaan ini, tanyakan tentang hal itu pada diri partisipan. Kembali ke no. 8, dan sesuai dengan respon partisipan, apabila partisipan ingin mengulang etude 2 kali, maka akan diulang 2 kali, namun apabila partisipan ingin mengulang etude 4 atau 5 kali, maka akan diulang sebanyak 4 atau 5 kali.

Setelah itu, peneliti melakukan post-test dengan materi tangga nada $\mathrm{E}$ minor, kadens E minor, trinada E minor, Honeybees' Attack. Berdasarkan hasil post-test pemula dewasa ke-1 menunjukan gejala nervous tangan berkeringat. Sedangkan pada pemula dewasa ke-2, tangannya masih dingin dan bahunya sesekali masih naik.

3. Tahap Refleksi

Berdasarkan hasil observasi, maka pada pertemuan berikutnya, peneliti akan mengulang siklus II pada pertemuan berikutnya.

Pertemuan 2

1. Tahap Perencanaan

Peneliti mengatur waktu pertemuan, menyiapkan materi dan media penelitian.

2. Tahap Observasi dan Implementasi Posisi Setengah Terlentang

Tindakan yang diberikan adalah dengan memberikan materi pre-test pada pelatihan piano yaitu: tangga nada $\mathrm{E}$ minor, kadens $\mathrm{E}$ minor, trinada $\mathrm{E}$ minor,
Honeybees' Attack. Kemudian peneliti menerapakan posisi setengah terlentang dengan menambahkan tindakan psikologis kepada kedua pemula dewasa. Setelah itu, peneliti melakukan post-test dengan materi Beyer No.5 Berdasarkan hasil post-test pemula dewasa ke-1 menunjukan gejala nervous sudah berkurang secara signifikan. Namun pemula dewasa ke-1 masih merasa deg-degan ketika memainkan piano. Sedangkan pada pemula dewasa ke-2, peneliti menemukan bahwa tangannya sudah tidak dingin lagi namun bahunya terkadang naik ketika memainkan karya yang belum dikuasainya.

3. Tahap Refleksi

Berdasarkan hasil observasi, maka pada pertemuan berikutnya, peneliti akan mengulang siklus II.

Pertemuan 3

1. Tahap Perencanaan

Peneliti mengatur waktu pertemuan, menyiapkan materi dan media penelitian.

2. Tahap Observasi dan Implementasi Posisi Setengah Terlentang

Tindakan yang diberikan adalah dengan memberikan materi pre-test pada pelatihan piano yaitu: Beyer No. 5. Kemudian peneliti menerapakan posisi setengah terlentang dengan menambahkan tindakan psikologis kepada kedua pemula dewasa dengan tindakan sebagai berikut:

a. Guru mendemonstrasikan gerakan the semi-supine;

b. Guru menginstruksikan pemula dewasa untuk memperhatikan demonstrasi guru;

c. Guru menginstruksikan pemula dewasa untuk melakukan gerakan the semi-supine;

d. Guru menginstruksikan pemula dewasa untuk menekuk lututnya ke lantai; 
e. Guru menginstruksikan pemula dewasa untuk menyimpan bukunya di lantai (posisi buku berada di sebelah kiri, di depan pemula dewasa berlutut, sekitar 1 meter atau lebih dari posisi pemula dewasa berlutut);

f. Guru menginstruksikan pemula dewasa untuk membungkukan punggungnya sampai tulang belakang pemula dewasa lurus dan menyimpan kepalanya di atas buku;

g. Guru menginstruksikan pemula dewasa untuk berbaring dan meletakkan kepalanya di atas buku;

h. Guru menginstruksikan pemula dewasa untuk menekuk lututnya saat berbaring dan menyimpan kedua telapak kakinya di lantai;

i. Guru menginstruksikan pemula dewasa untuk membiarkan tubuhnya berada dalam posisi terebut untuk beberapa saat sambil bernafas;

j. Guru menginstruksikan pemula dewasa untuk memposisikan kedua tangannya pada samping perut;

k. Guru menginstruksikan pemula dewasa untuk mengangkat kedua tangannya kesamping sambil menarik nafas dan memposisikan kedua tangannya kembali. Pemula dewasa melakukan hal tersebut berulangulang selama sepuluh kali;

1. Guru memberikan pertanyaanpertanyaan dengan menggunakan pendekatan psikologis kepada pemula dewasa yaitu sebagai berikut :

1) Bayangkan bahwa partisipan sedang memberikan pertunjukan piano.

2) Dimana partisipan sekarang? Diatas, bawah, kiri, atau kanan panggung?

3) Jika partisipan tidak gelisah sekarang, ingatlah apa yang partisipan rasakan saat ini.

4) Bayangkan seluruh bagian tubuh partisipan.

5) Sadarilah bahwa kecemasan adalah rekasi terhadap terhadap permainan piano partisipan. Hadapilah! Kecemasan itu adalah sesuatu yang ada dibawah kontrol partisipan.

6) Buatlah keputusan sadar untuk melakukan sesuatu yang berbeda dalam menanggapi perasaan kali ini: Partisipan tidak akan melakukan hal yang sama yang selalu partisipan lakukan. Agar perasaan itu berubah, partisipan hanya akan membiarkan perasaan itu berada di sana, beri diri partisipan kebebasan untuk merasakannya terlebih dahulu.

7) Pilih sensasi yang yang akan partisipan rasakan saat ini, dan berikan rasa ingin tahu tentang hal itu.

8) Katakan pada diri partisipan seperti apa rasanya.

9) Apakah partisipan benar-benar merasakan perasaan ini?

10) Untuk beberapa saat, tanpa berusaha membuat rasa cemas hilang. Jangan mencoba bersantai, bergerak, atau melakukan hal lain.

11) Adakah perasaan lain yang menarik perhatian partisipan? Jika ada alihkan perasaan partisipan kepada perasaan ini, tanyakan tentang hal itu pada diri partisipan. Kembali ke no. 8, dan sesuai dengan respon partisipan, apabila partisipan ingin mengulang etude 2 kali, maka akan diulang 2 kali, namun apabila partisipan ingin mengulang etude 4 atau 5 kali, maka akan diulang sebanyak 4

Jurnal Penelitian Pendidikan 
atau 5 kali.

Setelah itu, peneliti melakukan post-test dengan materi D Mayor, kadens D Mayor, dan trinada D Mayor. Berdasarkan hasil post-test kedua pemula dewasa sudah bisa memainkan karya piano dengan relaks.

3. Tahap Refleksi

Berdasarkan hasil observasi, maka penelitian ini dicukupkan pada pertemuan 3 siklus II.

\subsection{Pembahasan}

1. Nervous pada Siswa Piano Usia Dewasa

Pada penelitian ini terdapat dua siswa piano usia dewasa yang mempelajari piano dari tahap dasar. Berdasarkan kondisi tersebut, kedua siswa piano ini dikategorikan sebagai pemula dewasa. Hal ini sesuai dengan salah satu kategori siswa piano pemula dewasa yang dikemukakakan oleh Uszler (Mei, 2008, hlm.1) "College non-music majors (roughly eighteen to twenty-four years old." Uszler menjelaskan bahwa kategori pemula dewasa dalam bermain piano adalah siswa dengan berlatar belakang non musik dengan usia sekitar 18 sampai 24 tahun.

Saat memainkan piano, kedua pemula dewasa mengalami nervous. Gejala-gejala nervous yang timbul adalah gemetar saat memainkan piano, berkeringat dingin, tangan dingin, muka memerah dan bahu yang naik. Hal ini sesuai dengan gejala nervous dalam bermain piano yang dikemukakan oleh profesor neorologi dari Amerika, Antonio Damasio. Damasio (Lofnes, 2010) mengemukakan bahwa,

One of the problems for persons with low self-esteem is that they tend to interpret emotions in a negative way. They seem to forget that it is normal to feel nervous in many situations, and that everybody gets nervous reactions in the body, like increased pulse, blushing, cold sweating and the feeling of trembling. (hlm.8)
Damasio menjelakan bahwa nervous merupakan emosi yang normal, namun kebanyakan pianist menginterpretasikan emosi nervous dengan berkeringat dingin, muka memerah, dan tangan gemetar.

2. Posisi Setengah Terlentang untuk Mengatasi Nervous pada Siswa Piano Usia Dewasa.

Berdasarkan hasil dari identifikasi masalah, terdapat sebuah metode untuk mengatasi nervous. Metode tersebut adalah teknik Alexander posisi setengah terlentang. Pada penelitian ini, peneliti menerapkan posisi setengah terlentang kepada pemula dewasa melalui dua siklus.

Secara umum, penerapan teknik Alexander posisi setengah terlentang berhasil diterapkan kepada kedua pemula dewasa. Pada pemula dewasa ke-1 penerapan posisi setengah terlentang berhasil dilakuka pada fase ke-3. Keberhasilan penerapan posisi terlentang pada pemula dewasa ke-1 terlihat dari hilangnya gejala-gejala nervous berupa muka memerah, tangan yang dingin, dahi dan tangan yang mengeluarkan keringat.

Sedangkan keberhasilan penerapan teknik Alexander posisi setengah terlentang pada pemula dewasa ke-2 terlihat dari gejalagejala nervous yang hilang berupa bahu yang naik menjadi turun, tangan gemetar menjadi tenang pada fase ke-3.

Hal ini sejalan dengan teori posisi setengah terlentang yang dikemukakan oleh Heirich (2005, hlm. 49),

Semi-Supine is found to be a very effective resting position, yet it is more than merely restful. Not only does it give us an opportunity to undo the excess habitual tensions of our daily lives, but it also has the profound effect of reorganizing the head, neck, and spine. Therefore it is restorative and "constructive" as well as restful. Berdasarkan penjelasan tersebut maka 
posisi setengah terlentang merupakan posisi istirahat yang sangat efektif. Tidak hanya untuk melepaskan ketegangan tetapi juga memiliki efek untuk meningkatkan koordinasi antara kepala, leher, dan tulang belakang.

\section{KESIMPULAN}

Penerapan teknik Alexander posisi setengah terlentang pada siswa piano penderita nervous ketika memainkan piano, menghasilkan prototype model mengajar piano untuk siswa penderita nervous usia dewasa. Keunggulan penelitian ini adalah; melalui penerapan teknik Alexander posisi setengah terlentang pada pelatihan piano pada pemula dewasa dapat mengatasi nervous nya tanpa mengikuti perawatan medis atau pelaksanaan terapi.

\section{DAFTAR RUJUKAN}

Amiel, T., \& Reeves, T. C. (2008). Design-Based Research and Educational Technology: Rethinking Technology and the Research Agenda. Educational Technology and Society, 11.

Anderson, T., \& Sattuck, J. (2012). Design Based Research: A Decade of Progress in Education Research. American Educational Research dan SAGE Publication DOI: 10.3102/0013189X11428813.

David. (2017). Analisis Sikap dan Tingkat Kepuasan Konsumen Braga Music Studio Cabang BTC. Jurnal Manajemen Universitas Maranatha.

Davidson, J. W., Sloboda, J. A., \& Howe, M. J. A. (1996). The Role Parents and Teachers in The Success and Failure of Instrumental Learners. Bulletin for The Council of Research in Music Education, 127(15), 4044.

DBRC. (2003). Design-based research: What we learn when we engage in design. The Journal of the Learning Sciences, 11(1), 105-121.

Dede, C. (2005). Why Design-Based Research is Both Important and Difficult. Journal Storange, 45(1), 5-8.

Kali, Y. (2008). The Design Principles Database as means for promoting design-based research. In A. Kelly, R., Lesh \& J. Back (Eds). Handbook of design research methods in education (hlm. 423-438). London Roiutledge.

King, H. (2013). Alexander Technique and Anxiety Conditions. [Online]. Diakses dari http://www.hilaryking.net/ alexander-tejchnique/alexander-technique-and-anxiet.html.

Lofnes, I. (2010). Dealing with Nervousness. Oulu University of Science, Finland.

Mei, H. (2008). The Effect of Performance-Oriented Music Apreciation Class on Beginning Adult Piano Study. (Disertasi). University of Illinois, Urbana.

Pool, J., \& Dorothy, L. (2016). Design-based research: is this suitable methodology for short-term projects?. Journal Educational Media International, 53 (1), 42-52. Doi: https://doi.org?10.1080/09523987.2016.1 189246.

Shattuck, J., \& Anderson, T. (2013). Using a design-based research study to identify principles for training instructors to teach online. The International Review of Research in Open and Distributed Learning, 14(5). Doi: https://doi.org/10.19173/irrodl.v14i5.1626.

University of Oxford. (2005). Oxford Learner's Pocket Dictionary. China: Oxford University Press.

Wang, F., \& Hannafin, M. (2005). Design-based research and technology-enhances learning enviorenments. Educational Technology Research and Development, 43(4), 5-23.

Wong, L. H., Boticki I. S. J., \& Looi, C. K. (2011). Improving the scaffolds of a mobile-assisted Chinese character forming game via a design-based research cycle. Computers in Human Behavior, 24, 1783-1793. 